8. 解コウ飞特ける局部電池の起電力は高温なほど， 多少小さくなるが，水素過電圧はそれ以上に極端に小さ くなるので, 結局, $n$ は高温な泩ど, 減少する.

9. 以上の結果を用いて解コウ塔を設計する手順を例 示与る：

$100 \mathrm{kA}$ コウ和ソウに付帯すべき解コウ塔が

$\begin{array}{lll}\text { 生産カセイソーダ濃度 } & 40 \% \\ \text { アマルガム濃度 } & \text { 塔頂 } & 0.20 \% \quad\left(y_{0}=1.75 \times 10^{-2}\right) \\ & \text { 塔底 } & 0.002 \% \quad\left(y_{1}=1.75 \times 10^{-4}\right) \\ \text { 操作温度 } & & 90^{\circ} \mathrm{C}\end{array}$

で運転される場合, 水銀流量は $53.3 \mathrm{l} / \mathrm{min}(216 \mathrm{~kg}$ $\mathrm{mol} / \mathrm{h})$ となる.

（i）仮炕単位断面積当りの流量を $330 \mathrm{~kg}-\mathrm{mol} / \mathrm{h} / \mathrm{m}^{2}$ とすれば 所要断面積 $0.665 \mathrm{~m}^{2}$

となる。

(ii) 図1 拓よび図7より上記の条件では

[H.T.U.] $=10.16(\mathrm{volt} \cdot \mathrm{m})$

[N.T.U.] $=3.95 \times 10^{-2}\left(\right.$ volt $\left.^{-x}\right)$

であるから

所要塔高 $0.40 \mathrm{~m}$
となる。

（昭 34-4-1 受理）

\section{文 献}

1）日根交男，吉沢四郎，本誌 27，531 (1959)。

2) 日根交男，吉沢四郎，久代二郎、横田範之，本誌 $28 ， 7$ (1959),

3) 仁さえば 化学工学便覧，P.485 (1958) (丸善)。

4) Kとえば International Critical Tables VI, p. 254. (1929).

5) 日㮛交男, 成田勝, 吉沢叫郎, 閂田辰三, 本誌 27,134 (1959).

6) 日根交男, 吉沢四郎, 風田辰三, 本誌 27, 172 (1959).

7）日根文男, 吉沢四郎, 本諗 27, 475 (1959).

[使用した符号々単位]

$S:$ 解コウ塔断面皘 $\left[\mathrm{m}^{2}\right]$

$H:$ 充てん層の高さ $[\mathrm{m}]$

$K$ : 総括 (物筧移動) 你数 $\left.[\mathrm{kg}-\mathrm{mol}] / \mathrm{volt} \cdot \mathrm{m}^{3} \cdot \mathrm{h}\right]$

$E_{h}$ : 军用的駆勘力 $\left(=E-\pi h^{0}\right)$ [volt]

$E:$ 局部電池の起電力 $[$ volt $]$

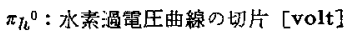

$Y:$ アルルカム中のナトリウムの活量 $\left[\mathrm{kg}-\mathrm{mol} / \mathrm{m}^{3}\right]$

$\kappa$ : カ女イソー夕の電導度 $[\mathrm{mho} / \mathrm{m}]$

$x:$ 水 $1 \mathrm{~kg} \cdot \mathrm{mol}$ 当りのカセイソータの kg-mol 数

$y:$ 水銀 $1 \mathrm{~kg}-\mathrm{mol}$ 当りのナトリウムの $\mathrm{kg}-\mathrm{mol}$ 数

$k_{A}:$ アマルカム侧物躓移動係数 $[1 / \mathrm{volt} \cdot \mathrm{h}]$

$k_{B}$ : 解コ口材㑡物啠移動保数 $\left[\mathrm{kg} \cdot \mathrm{mol} / \mathrm{volt} \cdot \mathrm{m}^{3} \cdot \mathrm{h}\right]$

$k_{F}:$ 電場形状保数 (または液内物質移動保数) [kg-rnol/amp $\left.\cdot \mathrm{m}^{2} \cdot \mathrm{h}\right]$

[स.T.U.]：解コウ塔に求ける1移動単位相当高さ [volt.-m]

[N.T.U.] : 解בり塔に打ける移動単位数 [1/volt]

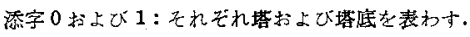

\title{
各種放電条件による, カドミウム電極表面の微細構造の変化* Changes of Fine Structure of Cadmium Electrode Surface by Various Discharge Conditions
}

\author{
吉 沢 四 郎**，竹原善一郎** \\ Shiro Yoshizawa, Zenichiro Takehara
}

\section{1. 緒言}

前報 》において，カドミウム水酸化物電極の充放電反 忘による表面構造の変化の電子影微鏡で観察した結果に ついて報告した，本報では，更に，カドミウム電極の放 電反応による表面構造の変化を，電子顕微鏡観察により 詳細に追跡したので，その結果を報告する。

前報1)では，特に，自己放電による表面状態の変化を 除去する目的で，試料の作製は，電子顕微鏡用レプリカ 膜作製まで䇪素ふん囲気中で行なった。とてろが，との 操作には，長時間を要するため，放電生成物である水酸 化力ドミウムの熟成, 溶解などか起とり, 表面構造が変 化する危険性がある．本報では，乙の点に留意し，溶液 中に長時間放置したために生ずる電梗表面の変化をでき

\footnotetext{
* 昭和 33 年 11 月 23 日 化学関保学協会連合秋季研究発表大会 （東京）にて発表

** 京都大学工学部工業化学教室 (京都市左宗区吉田本町)
}

るだけ少なくするよう努力した。

また，電極表面での電流分布が不均一である場合には 前派》に示したように，電極表面の各部分で充放電の程 度が異なる，そのために，本研究では，電極面での電流 分布の均一化にも注意を払った。

\section{2. 実 験方 法}

カドミウム活物質の表面構造, 厚さなどが常に同一で なければ再現性のある結果が得られないので現在実用さ れているカドミウム活物質を使用することはできなかっ た。 そしで，前報点と同様の方法で，カドミウム電極を 作製した。すなわち羽布研磨および電解研磿した $2 \mathrm{~cm}$ $\times 1.5 \mathrm{~cm}$ の大きさ(厚さ $0.5 \mathrm{~mm}$ ) のニッケル板の片 面に，酸化力ドミウム $31 \mathrm{~g} / l$ およびシアンカリ $135 \mathrm{~g} / l$ を含む電解液中で $30^{\circ} \mathrm{C}, 100 \mathrm{~mA}$ の電解条件で $10 \mathrm{~min}$

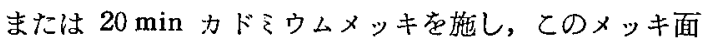
を 1 規定のカセイカリおよび 1 規定の硝酸カリを含む電 
解液中で $30^{\circ} \mathrm{C}, 50 \mathrm{~mA}$ の電解条件で $50 \mathrm{sec}$ または $90 \mathrm{sec}$ 陽極的に酸化し，電極表面に水酸化カドミウムとした. との電極を酸化力ミドウムを飽和した 4.5 規定のカセイ

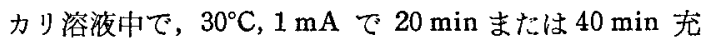
電を行い，さらに，30C の酸化カドミウムを飽和した 4.5 規定のカセイカリ溶液中あるいは酸化カドミウムを 飽和しない 4.5 替定のカ七イカリ溶液中心指定の電解 条件で放電を行なった。

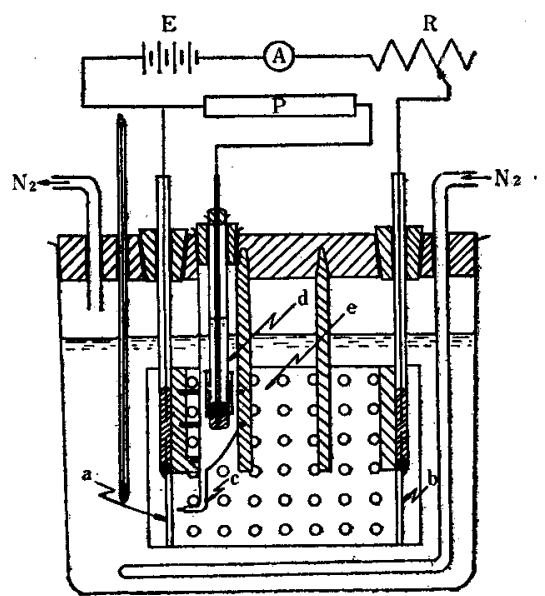

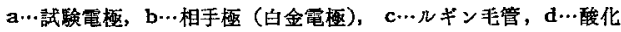
水銀電極 $(\mathrm{Hg} / \mathrm{HgO} / 4.5 \mathrm{~N} \mathrm{KOH}), \mathrm{e} \cdots$ 角型電解ソウ， $\mathrm{P} \cdots$ ポテ

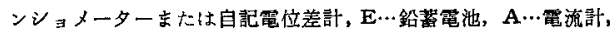
R...抵抗

図 1 実験に使用した電解ソウの模型図

図 1 に，充放電反応を行うために使用した電解りウの 模型図を示したままた，カドミウムメッキおよび陽極酸 化を行うための電解ソウとしては，図 1 亿示した電解り ウから，ルギン毛管わよび照合電極を取り除いた構造の ものを使用した。メチール・メタアクリレート樹脂で， 図のような角型電解ソウを作製し，電解中，電極面での 電流分布ができるだけ均一になるよう留意した。また， ソウ内での温度分布, 濃度分布をできるだけ均一にする ために, 角型電解ソウの側壁および底部に沢山の孔を穿 ち，角型電解ソウ自体は，ガラスソウ中に固定した。さ らに，てのガラスソウは恒温ソウ中に備えつけた。また 外気と電解液を遮断するために使用したゴ么栓は，いず れも塩化ビニール樹脂およびメタアクリレート樹脂で被 覆し, 電解液中にゴムが溶出しないように留意した。電 極毫面も，同様の被覆を行い，十分に絶緣を施した．特 に，充放電を行う場合には，電解中，絶えず外部より $.450^{\circ} \mathrm{C}$ の銅網上を通して酸素を除去した辤素を通気し， 自己放電の防止掞よびカキマゼを行った。電位は，図 1 に示したように，ルギン毛管を使用し，4.5 規定の力セ イカカリを電解液として使用した酸化水銀電極に対して測 定した。

目的の放電反応終了後，電極を取り出し，直ちに，尘
素ふん囲気中で, 䁷素を飽和した蒸溜水で短時間洗浄し その後エタノールで洗浄, 乾燥後直ちに $15 \%$ ポリスチ レンを含むべンゼン溶液中に浸せきした，その後，電極 を取り出し，窒素ふん国気中で乾燥しだ。このように して作製したポリスチレン被膜を前報 ${ }^{1)}$ と同様な処理を 行なって，電子顕微鏡用レプリカ膜を作製した。一方, 同様な操作により，エタノール洗浄まで行なった試料を 5\%のポリスチレンを含さベンゼン溶液中に浸せきし， うすいポリスチレン被膜を電極表面に作製した。このよ うにして, 表面を大気より遮断した電極面を， $\mathrm{X}$ 線回折 用の試料とした。

\section{3. 実 験 結 果}

写真 (a) に力ドミウムメッキ面を，写真 (b) にカドミ ウムメッキ面をカセイカリと硝酸カリを含む溶液中、で $90 \mathrm{sec}$ 陽極酸化した電極面を，写真 (c)にこの電極を更 に40min 充電した電極面を示した。また，図 2 に, 各種 の力ドミウム電極の定電流放電に対する電位と容量の関 係図を示した。図中の B,C,D は，いずれも写真 (c) に 示した電極を，酸化力ドミウムを飽和したカセイカリ 溶液中で， $0.5 \mathrm{~mA}, 1 \mathrm{~mA}, 10 \mathrm{~mA}$ で放電した場合の電位 と容量の関係を, $\mathrm{A}$ は, 写真 (c) に示した電極を酸化力 ドミウムを含まない力セイカリ溶液中で $0.5 \mathrm{~mA}$ で放電

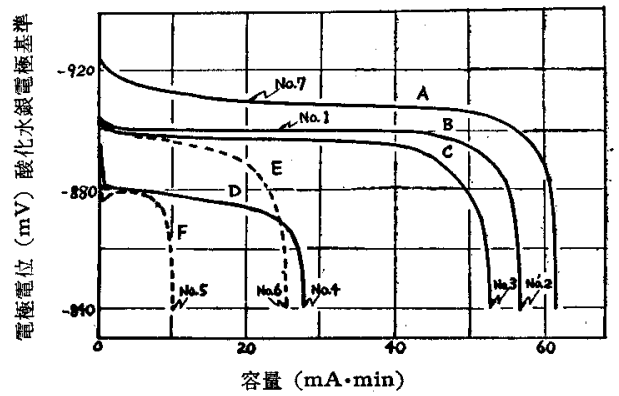

\begin{tabular}{|c|c|c|c|c|c|}
\hline & 出 & 電 & 極 & 電 解 液 & 牧正流 \\
\hline & ガトミウウ & 陽極酸化 & 充 電 & 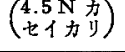 & 政琶琵狆 \\
\hline A & $\begin{array}{l}100 \mathrm{~mA} \text {, } \\
20 \mathrm{~min}\end{array}$ & $\begin{array}{l}50 \mathrm{~mA} \\
90 \mathrm{sec}\end{array}$ & $\begin{array}{l}1 \mathrm{~mA} \text {, } \\
40 \mathrm{~min}\end{array}$ & $\begin{array}{l}\text { 酸化力口 } \\
\text { ウム含まず }\end{array}$ & $0.5 \mathrm{~mA}$ \\
\hline B & $"$ & " & " & 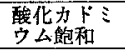 & $0.5 \mathrm{~mA}$ \\
\hline C & " & " & " & $"$ & $1.0 \mathrm{~mA}$ \\
\hline D & $"$ & $"$ & $"$ & $\Rightarrow$ & $10.0 \mathrm{~mA}$ \\
\hline $\mathrm{E}$ & $\begin{array}{l}100 \mathrm{~mA}, \\
10 \mathrm{~min}\end{array}$ & $\begin{array}{l}50 \mathrm{~mA}, \\
50 \mathrm{sec}\end{array}$ & $\begin{array}{l}1 \mathrm{~mA} \text {, } \\
20 \mathrm{~min} \\
\end{array}$ & $"$ & $0.5 \mathrm{~mA}$ \\
\hline $\mathbf{F}$ & " & - & 一 & $"$ & $10.0 \mathrm{~mA}$ \\
\hline
\end{tabular}

図 2 各種カドミウム電極の定電流放電に対する 電位・容量線図

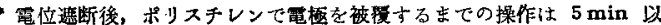
内て行なった，前報りに比へて，酸索に上る自己放電は幾分ま好かれ ないがしかし，ほとんと酸䒺に上る影掏は現われていないものと思

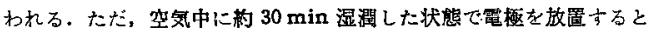

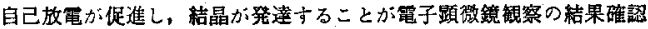
された。
} 
した場合の電位と容量の関係を，Eははガミウムメッ キ面を，カセイカリを硝酸カリと含む溶液中で $50 \mathrm{sec}$ 陽極酸化した電極面を $20 \mathrm{~min}$ 充電し，さらに， $0.5 \mathrm{~mA}$ で放電した場合の電位と容量の関係を，Fは，写真 (a) そ示したカドミウム面を $10 \mathrm{~mA}$ で放電した場合の電位 と容量の関係をそれぞれ示した。また，写真 (d)〜 (j) 飞図 2 の図中の No. 1 7 の状態に対応する電極表面の 電子顕微鏡写真を示した。また，写真 $(\mathbf{k})$ 亿は，図 2 No. 2 の状態の電極を, さらに $30^{\circ} \mathrm{C}$ で $10 \mathrm{~h}$, 酸化力ド
ミウムを飽和した 4.5 規定カセイカリ中に放置した場合 その電極面で比較的よく水酸化カドミウム結晶が成長し た部分の電子顕微鏡写真を示した*。

また，図 3 にこ机ら電子影微鏡写真に示したもののう ち主なる電極面の，自記X線回折装眥を使用して湘定し た，Debye-Scherrer 法によるX線回折の結果を示した。

\section{4. 考察}

同一カドミウム電極（写真 (c) に示した電極) を使用

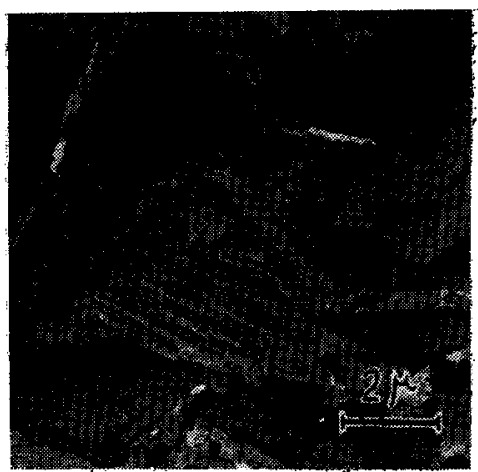

(a) Cd メッキ面

(策件: $30^{\circ} \mathrm{C}, 100 \mathrm{~mA}, 10 \mathrm{~min}$ メッ丰)

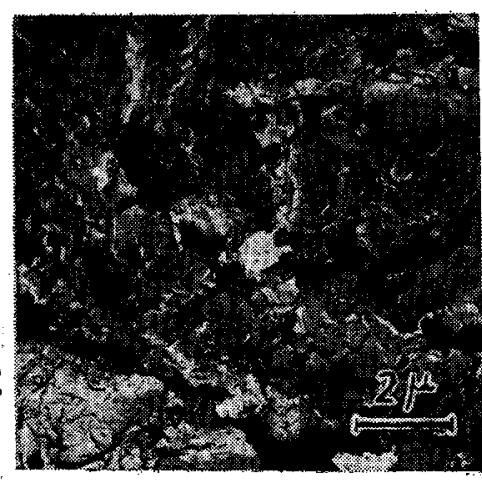

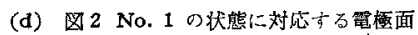

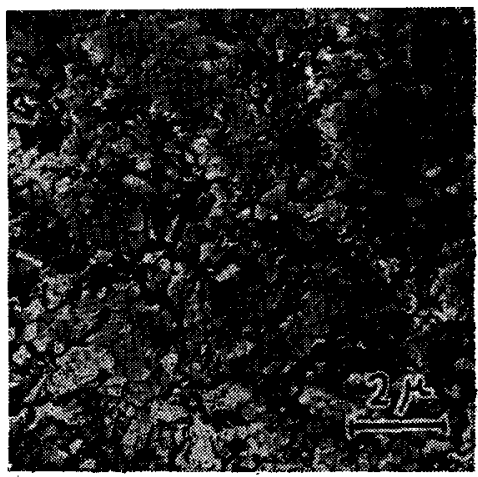

（g）図 2 No. 4 の状热に対応する電亟面

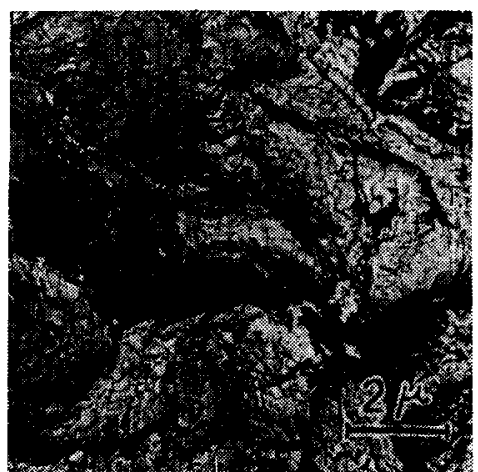

(b) $\mathrm{KOH} \longleftarrow \mathrm{KNO}_{3}$ を含む溶液中て陽極酸

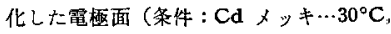
$100 \mathrm{~mA}, 20 \mathrm{~min}$, 陽極酸化 $\cdots 30^{\circ} \mathrm{C}, 50$ $\mathrm{mA}, 90 \mathrm{sec}$ )

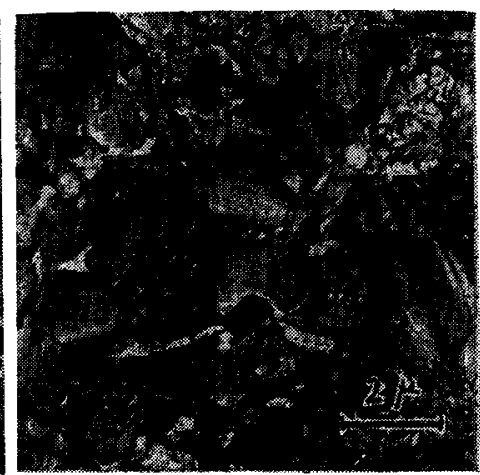

（e）図 2 No. 2 の状热に対芯寸る電極面

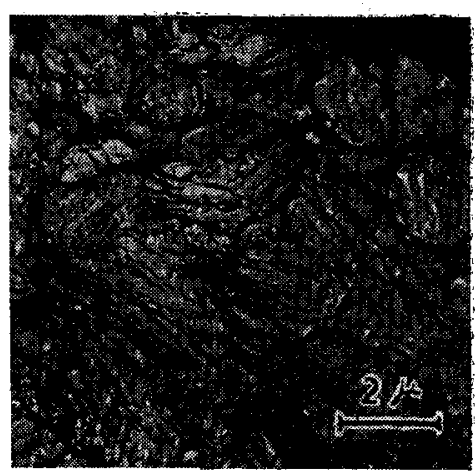

(c) (b) をさらに, CdO を蚫和した $4.5 \mathrm{~N}-$

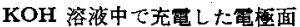
（条件：充電 $\cdots 30^{\circ} \mathrm{C}, 1 \mathrm{~mA}, 40 \mathrm{~min}$ )

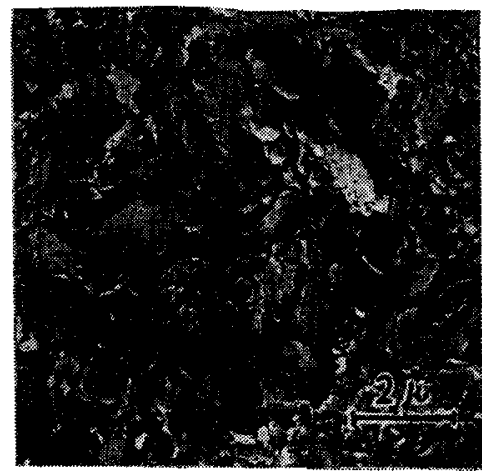

（f）四 2 No. 3 の状態に効忍ちる電極面

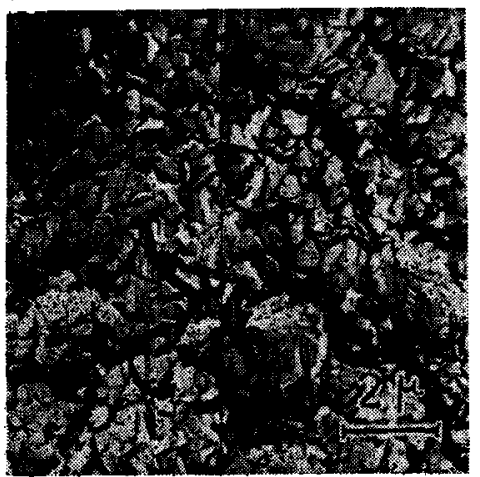

(h) 圀 2 No. 5 の状態に対応する電極面

・写真 (b),(c),(d),(e) は前報1) と重襩するが、説明の必要上写真の中に加えた。 


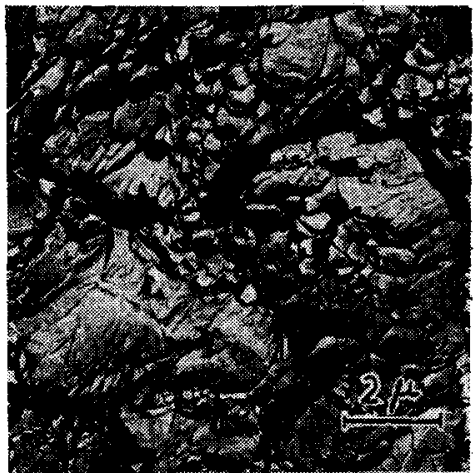

(i) 图 2 No. 6 の状態に対応する電極面

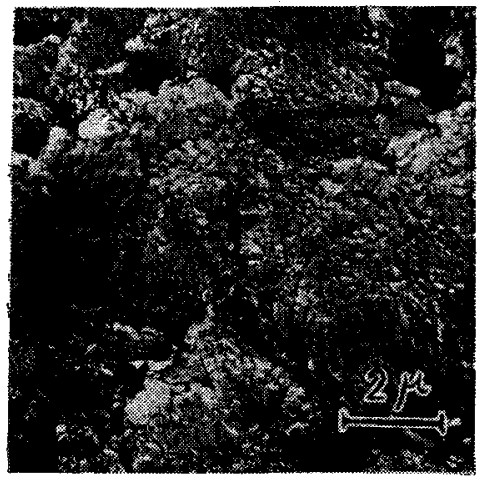

（j）目 2 No. 7 の状態に対応する電梅面

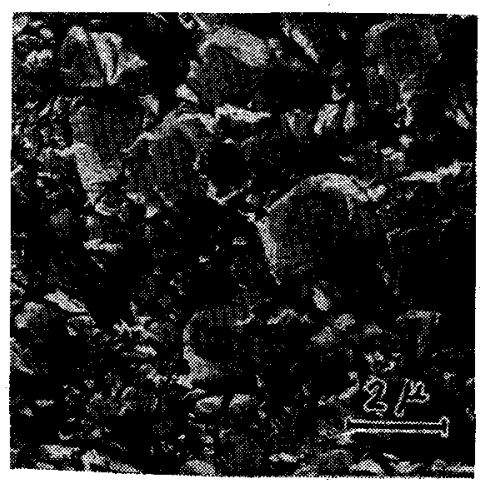

（k）（e）をさらに, $10 \mathrm{~h}$ CdO を飽和した 4.5 $\mathrm{N}-\mathrm{KOH}$ に放置した電極面（此較的 Cd $(\mathrm{OH})_{2}$ の結晶がよく成長している部分)

写真 1 各種放電条件による, カドる ウム電極表面の電子顕微鏡写真

して，放電及応を行う堭合，図 $2 \mathrm{~B}, \mathrm{C}$ および $\mathrm{D}$ 曲線に示したように，故電電 流が大となると，それに応じて著しく 電池の容量は娍少する，写真 (e),(f) および(g) と放電電流を上昇させた場合の，放電 䅂了時の電極表面の状態を示した，写

真 (e) に示したように，0.5 mA のような低電流放電に おいては，前報 ${ }^{1}$ と同様，1〜2 $\mu$ 程度の比較的大きな水

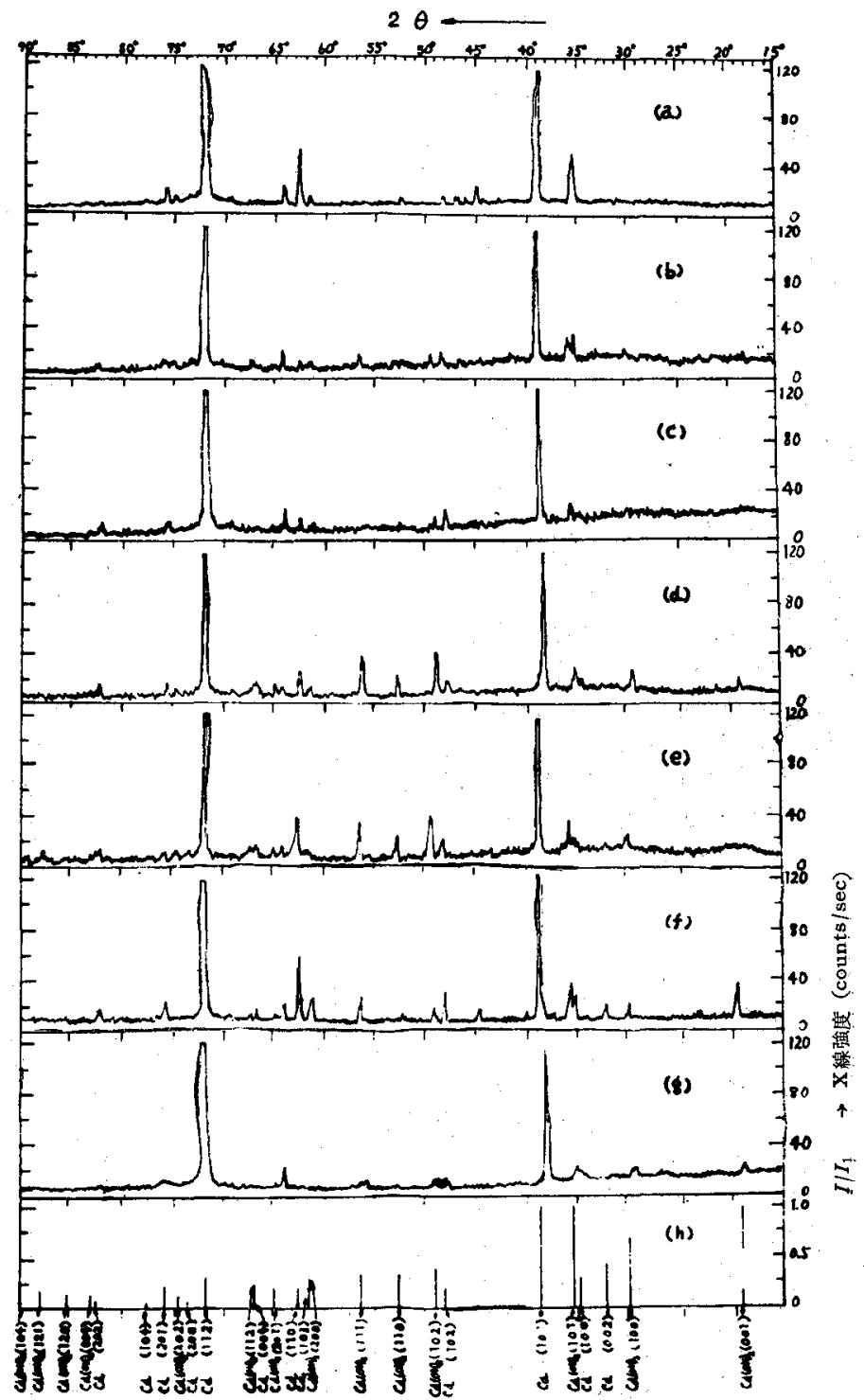

(a) 写真 (a) 仁示された笛極面の $\mathbf{X}$ 線回折四形

(b) 写真 (b) に示された電極面の $\mathbf{X}$ 線回折図形

(c) 写真 (c) に示された電極面の $\mathbf{X}$ 線回折园形

(d) 等真 (e)（四 2 No. 2) に示された䉓極面のX楾回折図形

(e) 写真 (g) (因 2 No. 4) に示された電掼面の $\mathbf{X}$ 線回折図形

(f) 写真 (h) (因 2 No. 5) に示された電極面のX線回折因形

(g) 写真 (j) (因 2 No. 7) に示された電極面の $\mathbf{X}$ 線回折四形

(h) Hanawalt ${ }^{2\rangle} に よ り$ 示された Cd おょび Cd(OH) 2 のX線回折線

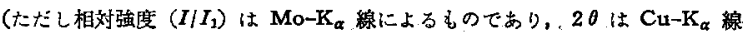
に対応するものである.）

因 3 各種のカドミウム—水酸化カドミウム電極の $\mathrm{X}$ 線回折図形 （分散スリット: $2 \mathrm{~mm}$; 榆出スリット $0.2 \mathrm{~mm}$ 電圧 : $34.5 \mathrm{kV}$; 電流 : $15 \mathrm{~mA}$; 陽極 : $\mathrm{Cu}$; フィルター: $\mathrm{Ni}$; 全

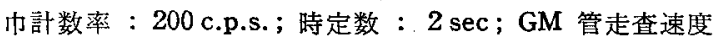
1 度 $/ \mathrm{min}$ )
酸化力ドミウム結晶が電極表面に点在している.一方, 写真 $(\mathrm{g})$ に示したように, $10 \mathrm{~mA}$ と放電電流が大とな 
ると， $0.2 \sim 0.5 \mu$ 程度の比較的小さい水酸化力ドミウ ム結晶が電極全面を覆い，しかも水酸化力ドミウムの 結晶粒の間で電亟面の溶解が認められるようになる。細 野3)，吉沢 ${ }^{4)}$ ，Lake ${ }^{5)}$ は，電位の測定結果から，力ドそ ウム電極の放電垱っては，まず中間生成物が生成し との生成物の溶解，または再配列を通して，新しい相に 水酸化力ドミウムが生成し，放電が進行すること在諗め ているが，てれら電子顕微鏡観察の結果妵，電位測定よ りの結果とよく一致している.低電流故電においては, 单位放電時間当りの放電生成物の量が少ないため, 特定 の結晶核索中心として水酸化力ドミウム結晶か娍長し, 大きな結晶へ三次元的に成長していく，そのため，長時 間の放電によっても有效なカドミウム面が常に表面に存 在し，この面を通して反忘が進行する，そのために，活 物曾の利用率が著しく向上する。一方，高電流放霄にお いては，笔位放電時間当りの放電生成物の量が著しく多 くなるため，特定の核を中心とする結晶の成脣が奶げら れ，電極面全面に一度に水酸化力ドうウム結晶が生成 する結果となる，そのため，高電流放電の場合は，絶䋑 体である安定な水酸化カドミウム結晶で，短時間の放電 により電槚面全体が覆われ，容量か㵔しく減少する。图 3 (d) 抢よび（e）に，写真（e）抢上び（g）の電檫面 のX線回折の結果を示した，細野泉 が示していると㤘様 カドミウムと $\alpha$ 型水酸化力ドミウム み友示した. Huber ${ }^{8)}$ が電子楾回折上り放電生成物とし ての酸化力ドミウムの存在在確認しているが，X線回折 の結果では酸化力ドミウムの存在は諰められなかった。 また，放電電流の変化によっては，ほとんど水酸化力ド ミウムの回折線には変化が諗められなかったが，ただ， 低電流放電になる程，各回折線が尖鋭となり特に(001) 面の回折線が尖鋭に現われる結果を示した。

見かけの放電電流密度が同一である場合でも，図 $2 \mathrm{D}$

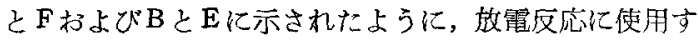
る力ドミウム電極の表面状態が異なれば，それに応して 電池の容量は著しく変化する・カドミウムメッキ面では， 容量加著しく小さいけれども，とのメッキ面を力セイカ リと硝酸力リを含む溶液中で陽極的に酸化してやると, その程度によって容量か湾化し，乙の操作条件か浩酰 である程容量㹥大する。乙の状態を示したのが，写 真（a）と（c）である. 同じカドミウム面でも写真 (c) の塂含は，表面の凹凸か著しく，表䤄積が著しく大とな っていることが予想される、図3 (a) と（c）に，それ ぞれの面に対灾するX線回折の結果を示した。図 3 (c) に示したように，陽極酸化の過程を経ると，力ドるウム の回折線は弱く，搪散した状堵になっており，これはカ ドミウムの結鼠か微絹化したためではないかと思われ

*六方晶系 c-6 型の層格子構造を有するが，をのX楾回折像はArnfelt 棈造特有の強度変化は示さない。
る**.す枋りち，陽極酸化の過程により電極表面のカド ミウムが微細化し，放電反応を受けやすくなると同時 に，表面積の增大によって真の電流密度が低下するた め, 容量加堌大するものと考无られる。一方, 図 3 (e) と（f）と比較すると，(f) の方が水酸化力ドミウムの (001) 回折線をはじ，各回折線汃尖鋭に現われており カドそウム結晶の発達した面では，放電によって生成す る水酸化力ドミウム結晶もよく発達するととが予想でき

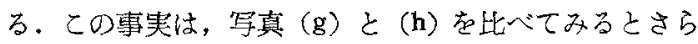

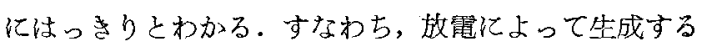
水酸化力ドミウムは素地のカドミウム面之何らかの関係

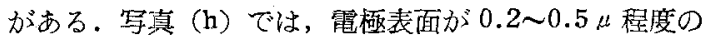
微細なよく発達した水酸化カドミウム結晶で覆われ，表 面方著しく絶縁体化しているものと思われる。一方，写 真（g）では，生成している水酸化カドミウムの結晶の

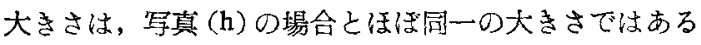
が，結晶の粒界において著しい溶解現象の跡が㫕られ， 結晶粒界で反応が進行しているととがわかる。すなわち 写真 (h) の場合亿结， $\mathrm{OH}^{-}$のカドミウム電極内部への 抎散が困難であるために放電によって電極面全体が速く 覆われるが，写真（g）の場合には，表面の力ドミウム 結晶加微細化しているために OH- はカドそウム雲極の 内部まで搪散しやすく，中間的劣反店力跑りやすい。す なわち，この中間的な反応が水酸化カドミウム結晶の梿 界沈小て進行し，二次的に生成する水酸化力ドミウム は，最初生成した水酸化力ド々ウムの上に積み重子。 て生成するととが予想できる。とれらの事象から，容量 の変化の原因は，表酒積の差異による真の雪流密度の変 化によると考えるよりも，むしろ陽極酸化住より，力ド そウム西力微細化し，電極内部まで $\mathrm{OH}^{-}$の圆相搪散が 可能となる結果，中閒生成物の生成が容易になり，その ために，力ドミウムの利用率がよく文ったと教えた方が より妥当であるように思われる。

写真 $(\mathrm{j})$ には，酸化力ドミウムを含まない麗解液中で の放電を行な。た場合の表面状態の変化を示した。この 写真は，カドミウム電極表面が著しく侵食され，溶解が 起っているとと宗している，写真(d)に，酸化力ド主 ウム应電解液中に慨和した場合の，0.5 mA 放電化よる 放電の中䦬段階における表面状態を示した。写真 (d)と （j）在比較すると，電極表面の溶解の過程がはっりと

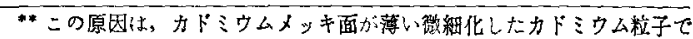
覆われたため, 遏板のカドミウムメッキ面に起因寸る回折線が弱めら れたことによるのではいかと思ら。写真 (c)に示された電極の表面

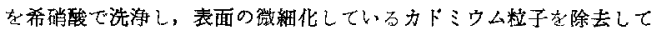

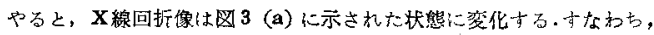
表面に存在する加トミウム粒子のために，X楾回折像力゙弱的られ，拢

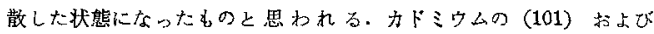
(102)面に相当与る国折線がとんと変化していないのは,カトミウム メッキ面に比へて，電解酸化および塄元を経下生成したカドミウムの

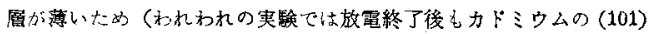

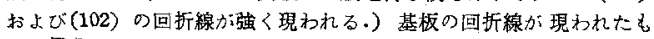
の思思。 
わかる.図3（g）に写真（j）に示した電楆面のX線回 折の結果を示した。との場合も，他の場合上同稼，カド ミウムと水酸化カドミウムの混合X線図のみ示し，酸 化力ドミウムの存在は認められなかった。カガミウムメ ッキ面を，力セイ力りと硝酸力り克含溶液中で，陽極 酸化した場合の表面状態を写真 (b) に，X線回折の結果 を図 3 (b) に示した。写真（b）および（j）に示した電極 面では，ともに，中間生成物が電解液中に溶解し*，表面 そ生成している生成物のX線国析像は著しく搪散した状 態にあることを示している，特に，図3（g)に示した水 酸化力ドミウムに対するX線回析像は拉散が著しい。す なわち，可溶性力ドミウムイオンを含まない電解液中で 放電虑行う場合注，故電によって，生成する生成物は， 十分結晶化していない無定形の水酸化カドミウムの構造 を有するものであるうと尒想できる。これらの結果よ り，電解液中に力ドミウムイオンが溶解していない場合 亿は，Lake ${ }^{5)}$ が示しているように，故電反応によって中 間生成物方生成し，乙の中間生成物注電解液中に溶解し そのため，安定ふ水酸化力ドミウム結晶の二次的な生成 が著しくさ末たげられるととがわかる、然た，この場合 は，力ドミウム自体による回折線も(101)および (112) 面以外は著しく抬散した状態にあり，力心゙ウムの結昆 自体も崩壊していくのではないかと思われる。

写真 (k) に $0.5 \mathrm{~mA}$ で放電した後, 電極学長時閏酸

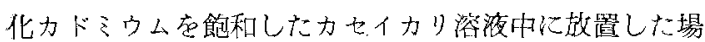
台の表面状態を示した。この军真㤬，水酸化力ドミかム

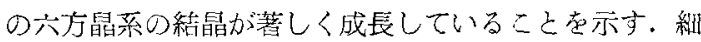

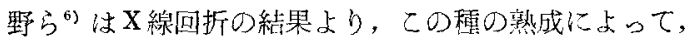

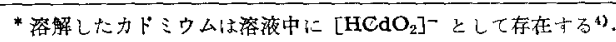

水酸化力ドミウムの結晶力湩しく成長し, 特に(001) 面 の成長が著しいと報告しているが，乙の事実は，電子顕 微鏡観察の結果己よく一致する。放電終了時の電極は， 黑色であるが，この種の熟成によって，著しく結晶が成

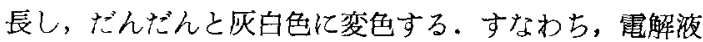
中に浴存しているカドミウムイオンあるいは電極面に存 在する水酸化力ドミウムが，乙の㮔の熟成によって，特 定の核を中心として成長していくことがわかる。

前街》では，電極面の場所によって故電反应走受ける 程度が買なっていた。すなわち，電極の周辺部では，中 心部に比べて，故電によって生成した水酸化力ドミウム の粒正か電極面古占める割合が大であった。としろが図 1 亿示した電解ソウの使用により，電極の場所による放 電反応を受ける程度が均一化され，電子顕微鏡㩁察の結 果汢，電極面の中心部 主周辺部もほぼ同一の結果を示し た、寸なわち，乙の種の電池反灾の研究においては，電 極面上での電流分布の均一化に対して十分注意する必要 があるように思う。

最後に，本研究を行うに当って，いらいろで指導を賜 わった京都大学岡田辰三名誉教授ならびにいろいろご助 言在頂いた本多電機松井正好氏に感謝する。

(昭 34-4-6 受理)

\section{文 献}

1) 吉沢四郎, 竹原善一郎, 棼井正好, 本誌 28, 10 (1958).

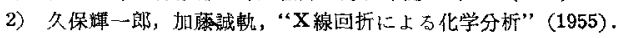

3）料野富造，松井正好，鈴不觜一，本誌 27，241 (1958).

4) 吉沢四腑，竹原善一郎，昭和 33 年 11 月電気化学協会心七発表.

5) P.E. Lake, E.J. Casey, J. Electrochem. Soc. 105, 52 (1958).

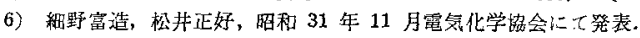

7) W. Feitknecht, Helv. Chim. Acta 39, 584 (1956).

8) K. Huber, J. Electrochem. Soc. 100, 376 (1953).

\title{
水溶液中におけるフッ化リチウムのイオン水和状態に対する メタノール，エタノールの影響について一フッ化リチウムの 溶解度およびその溶夜の導電度*
}

\section{The Effects of Methanol and Ethanol on the States of Ionic Hydration of Lithium Fluoride in Aqueous Solution-Solubility of Lithium Fluoride and Electroconductivity of its Solution}

\author{
和田悟 朗**, 伊藤千賀子***, 堀江喜美子*** \\ Goro WADA, Chikako ITO, Kimiko HoRIE
}

\section{1. 緒言}

LiFはあらゆるアルカリハライドの中で，その構成イ

- 溶波內におけるイオンの溶媒和現象（第 6 報） Tonic Solvation in Solutions, (Part 6) 昭和 34 年 4 月 2 日, 日本化学会第 12 年会発表 (京都大学)

***得戸大学理学部化学教室（神戸市東御影町）

*** 神戸女子洎科大学（神戸市東整区本山町）
オンの大きさがもっと毛小さいものであり，また，水に 対す万溶解度の小さい点において子唯一の例外的存在で あ万、水が常温村近の温度に扔いて子微視的な偽結鼠構 造哑もっているといらことは，すでによく知られている が，この上うな水に電解質か綌解しているときは，1才 ンと水分子との相互作用によって，その偽結晶構造加乱 さ礼る，たとえば， $\mathrm{KCl}$ から生しる $\mathrm{K}^{+}$亿オンや $\mathrm{Cl}^{-}$ 